\title{
Proselyting in First-contact Situations as an Instructed Action
}

\author{
TAMAH SHERMAN* \\ Charles University, Prague
}

\begin{abstract}
Drawing on ethnomethodology and conversation analysis, this study examines the phenomenon of proselyting in first-contact public situations as conducted, learned, continually developed, and reflected by American Mormon missionaries from the Church of Latter-Day Saints (LDS) in the Czech Republic, with a focus on first-contact public proselyting (FCPP) encounters. Proselyting is analysed as an instructed action and as a situation in which one party is initially aware of the category of encounter which is to take place, while the other party (or parties) is not, and it is necessary to create the particular type of encounter and then to execute it in some effective and beneficial way as defined by the first party. I examine the types of order to which both parties orient in these situations, i.e. local and extended sequential order, topical order, and categorial order, as they are layered in the doing of the instructed action. The findings demonstrate that, as opposed to the lay perception that religious missionaries simply recite learned passages and phrases in doing their proselyting work, their activities in fact involve complex sequences of communicative work which require the utilisation of experience, tacit knowledge, and creativity. In addition, while it is possible to flesh out and describe a clear sequence of phases in FCPP encounters which, from the outsider's perspective, constitute proselyting, there is little which otherwise differentiates it from other types of activities involving talk.
\end{abstract}

Keywords: missionaries, LDS Church, instructed actions, proselyting, ethnomethodology, conversation analysis

Sociologický časopis/Czech Sociological Review, 2010, Vol. 46, No. 6: 977-1009

\section{Introduction}

This study examines the phenomenon of proselyting in first-contact public situations as conducted, learned, continually developed, and reflected by American Mormon missionaries from the Church of Latter-Day Saints (LDS) in the Czech Republic. ${ }^{1}$ Proselyting is understood from two perspectives: as attempting to con-

\footnotetext{
* Direct all correspondence to: Tamah Sherman, Institute of Linguistics and Finno-Ugric Studies, Faculty of Arts Charles University in Prague, nám. Jana Palacha 2, 11638 Prague 1, Czech Republic, e-mail: tamah.sherman@ff.cuni.cz.

1 This article has been adapted in part from Sherman [2007]. The research was supported by the Czech Science Foundation grant GD405/03/H053 - Jazyk a diskurs and the research aim MSM0021620825 - Jazyk jako lidská činnost, její produkt a faktor. Thanks are

(C) Sociologický ústav AV ČR, v.v.i., Praha 2010
} 
vert others into a doctrine or religion, which is the perspective of those who are subject of the proselyting, or as spreading the gospel, which is the perspective of those who do the proselyting. Focus is placed upon what are termed first-contact public proselyting (FCPP) encounters. Data from these situations is used to address questions of the phenomenon of order, particularly sequential, topical, and categorial order. The analysis of order is highly pertinent to the understanding of proselyting as an instructed action. The theoretical basis for these concepts can be found in the framework of ethnomethodology [Garfinkel 1967, 2002; Heritage 1984; Francis and Hester 2004] and its associated fields of conversation analysis [Sacks 1992; Psathas 1995] and membership categorisation analysis [e.g. Jayyusi 1984].

In this study, I examine the following questions:

1. How do missionaries utilise the instructions they are given for the purposes of first-contact situations?

2. What interactional work is done to overcome problems encountered in the proselyting process?

3. How do the participants in these proselyting situations make relevant the given setting, in this case characterised by the contact between Czech (local) and American (foreign) languages and cultures?

4. How do missionaries utilise the trans-situational character of proselyting practices?

In answering these questions, I describe proselyting as an instructed action, and furthermore as a public situation ${ }^{2}$ and as a situation in which one party is initially aware of the category of encounter which is to take place, while the other party (or parties) is not, and it is necessary to create the particular type of encounter and then to execute it in some effective and beneficial way as defined by the first party. In addition, the analysis presented here also aims to contribute to the body of literature on ethnomethodology and conversation analysis as applied to situations defined by members (in Garfinkel's sense) as religious ones. ${ }^{3}$

\section{First-contact situations in the context of proselyting}

For the purposes of understanding the concept of proselyting as viewed by those practising it, it is necessary to provide a bit of background information on the context in which it is continually reproduced. The Church of Jesus Christ of

\footnotetext{
due to Jiří Nekvapil, Petr Kaderka and the two anonymous reviewers for their valuable comments.

${ }^{2}$ Research on encounters in public, beginning with Goffman [1963], is too extensive to recount here. Ethnomethodological work on these phenomena, however, has most recently included Llewellyn and Burrow [2008] and Mondada [2009].

3 This includes, for example, Liberman [2004], Capps and Ochs [2002], and Lehtinen [2005, 2009].
} 
Latter-Day Saints (LDS), also known as the Mormon Church, headquartered in Salt Lake City, Utah, organises a missionary programme that currently maintains 51736 missionaries per year throughout the world, ${ }^{4}$ including 90 in the Czech Republic and Slovakia, outside of the territory of 'Zion' (Utah), including the United States. Males are eligible to serve at the age of 19 and serve for two years, females are eligible at 21 and serve for a year and a half. ${ }^{5}$ The missionaries' journey begins with the submission of an application to the church, which determines where the missionaries will serve, after which they receive the 'Call to serve'. They subsequently attend the Missionary Training Center (MTC) in Provo, Utah, for language and practical training. The period of time spent in the Missionary Training Center is commensurate with the amount of linguistic preparation necessary for the mission. The missionaries assigned to the Czech mission (which includes Slovakia) spend nine weeks in the MTC, during which they spend 8-12 hours per day learning Czech.

Upon arrival in the Czech Republic, each missionary is assigned a 'companion', or another missionary of the same sex with whom the missionary spends all waking hours for a two-month period (known as a 'transfer'). This process is repeated every two months, and the missionary moves around to different parts of the mission territory and works together with many different companions. One companion, the 'senior companion', is the companion who has spent more time in the country and holds responsibility for further training of the junior companion, particularly as concerns language, communication, and intercultural issues. This older companion is expected to lead the younger one through the variety of day-to-day situations which comprise what is known to members as proselyting, or the spreading of the gospel. Most of this consists of meeting new people either through church members or through other activities, or by addressing people in public or going door-to-door, and arranging and conducting teaching sessions for those who are interested (known as 'investigators'). That is, most activity is comprised of talk.

The LDS proselyting approach contains two key elements. One is the fact that the church prides itself in the unity of beliefs of its 12 million members throughout the world. The other is that, at the same time, each individual missionary is encouraged, and, in fact, instructed, to develop a personal approach to faith, and a personal method of proselyting as well, one which corresponds to personal style. As one missionary commented on her practices in talking with people, 'we don't recite a set script, we say it in our own words'. It is then relevant to pose the questions of how these two elements are intertwined, and in which sorts of situations this intertwining is manifested.

\footnotetext{
${ }^{4}$ http://beta-newsroom.lds.org./facts-and-stats (retrieved 3 December 2010).

${ }_{5}$ While most active LDS males go on a mission, the same is not true for LDS females, who are viewed as having a different role, primarily that of devoting oneself to family. Hence, they are encouraged give precedence to marriage (if they have marriage prospects at that time) over serving a mission.
} 
When members of an organisation are given the same instructions and then sent to various parts of the world, their subsequent interpretation and following of these instructions can tell us much about the doing of their assigned activities. This article seeks to examine the process of proselyting in first-contact public situations as a members' method in the ethnomethodological sense, with the members being Czech-speaking American LDS missionaries. The missionaries act as members ${ }^{6}$ in the context of their religious group, but also in many cases as members in the context of their native country and language. Their aim is to make as much contact as possible, so they become researchers in their own right, continually storing away information, experiences and tacit knowledge for later use, both in further encounters and in instruction, to pass on to their companions. There are also methods within the process that make them missionaries, and that makes their work in these situations proselyting.

Laymen's questions of the missionary work include not only 'How is it that they are able do it?', but also 'Why are they doing it?'. In this study, I will add another, that is: 'What are they doing?' Previous sociological, anthropological, and linguistic studies of LDS missionary work have, among other things, addressed it from macro-sociological and organisational perspectives [Cornwall, Heaton and Young 2001], characterised 'the missionary experience' and the dynamics of the missionary companionship [Shepherd and Shepherd 1998, 2001; Knowlton 2001; Parry 2001; Wilson 2001], and characterised missionary linguistic code-mixing [Smout 1988]. But never before has proselyting been specifically studied as 'talk', nor has it been analysed using the research and analytical procedures of ethnomethodology, (hereafter EM), the study of the way in which people make sense of the world and display their understanding of it, or conversation analysis, the study of 'talk-in-interaction'.

To begin with, I take note of some the most common definitions of proselyting and then formulate an understanding of it that is relevant to this study. The word is often used interchangeably in an alternate form, 'proselytising', particularly in lay contexts. I use 'proselyting' here because it is a term used by the missionaries themselves and which appears in their manuals and other guidance materials, referring to missionary work in general. For example, the LDS Missionary Handbook lists 'proven methods' of proselyting, which fall into three categories: 'finding'7, 'teaching', and 'baptising and fellowshipping' [Missionary Handbook: 6-11].

\footnotetext{
${ }^{6}$ In this case, 'members' in an ethnomethodological sense should not be confused with members of the church.

7 This is further divided up into the following 'opportunities to find' or 'sources', which are 'listed in order of effectiveness': (1) recent converts, (2) baptismal services, (3) stake missionaries' contacts with members and non-members, (4) part-member families, (5) members in general, (6) former investigators, (7) current investigators (referral dialogue), (8) media, visitors' centers, and Church headquarters' referrals, (9) activation efforts (unknown address file), (10) service activities, (11) new move-ins, (12) special inter-
} 
Missionaries in the LDS church have blocks of time which are strictly determined for certain activities. In the local (i.e. the so-called Czech Prague) missionary handbook, there are materials which specifically state what can be considered proselyting and what cannot. The activities which 'pass for proselyting' are divided up into the different types of general activities - e.g. teaching, finding, planning/preparing, meetings, and serve more as an institutional guide in which proselyting could be made synonymous with 'working'.

As for definitions originating outside of the LDS church, the most common dictionary definition of proselyte is 'proselytise', which is defined twice as an intransitive verb as (1) to induce someone to convert to one's faith, and (2) to recruit someone to join one's party, institution, or cause, and once as a transitive verb - to recruit or convert especially to a new faith, institution, or cause. ${ }^{8}$ The differentiation between the transitive and intransitive definitions of the verb to proselyte or proselytise point to an emphasis on the question of 'success' of the proselyting process. It is thus possible to pose questions such as: if the intended convert ends the conversation, walks away, or changes his or her mind during the teaching and conversion process, has proselyting actually occurred? Given this question, this study focuses on the intransitive understanding of the process and defines proselyting in terms of 'interaction' and 'order'. That is, as composed of a series of previously identified phases which consist of at least one missionary summoning the interlocutor, establishing a categorial relationship between him/ herself and the interlocutor, finding out the interlocutor's stance on matters of the spiritual, and securing further contact to the interlocutor or a promise of a further meeting between the two. This study thus takes the view that proselyting is a 'course of action' that is done through 'members' methods' and 'talk-in-interaction'.

\section{First-contact situations, background, and data}

The data for this study consist of transcribed recordings of first-contact public proselyting (FCPP) situations which were gathered as a part of a larger, more extensive ethnographic research project [see Sherman 2007]. The project involved the collection of data from the following: individual first-contact situations, several of which were part of 'street displays', an activity in which missionaries sing in public (most often on a large square in the city) and take turns talking to passers-by; second-contact situations - English classes, stop-smoking seminars,

est contacts, (13) tracting, (14) street contacting, (15) speaking with everyone. It should be noted that the missionaries thus understand the sources analysed in this study, numbers 14 and 15, from the very beginning as activities which are very low in their effects and approach them accordingly.

8 This dual-transitivity meaning for 'proselytize' can be found in the Merriam-Webster Dictionary, the American Heritage Dictionary, and at Dictionary.com. 
informal language and/or spiritual teaching appointments, and organisational situations such as group meetings. The recorded data were transcribed based on the conventions of Conversation Analysis (specifically, a modified version of that used in Psathas [1995]). The individual FCPP situations were selected for analysis, i.e. categorised by the researcher as FCPP situations, on the basis of several conditions. These are (a) the encounter took place in public, (b) the missionaries and their interlocutors did not know each other previously, and most importantly, (c) the missionaries themselves categorised the activity as 'contacting', ${ }^{9}$ usually prior to doing it, e.g. by making statements such as 'we're going to go contacting now', or 'let's contact that guy'.

Proselyting may be observed by outsiders as consisting of phases, all of which involve some type of member-determined goal-oriented interaction - outside of the FCPP situations (cf. Arminem [2006: 135-138]), in interviews, the missionaries stated a number of goals connected to the situations. Though this approach may serve a certain purpose to the analyst, the phenomenon itself as an instructed action is a naturally occurring one, and these phases remain intertwined. Therefore, as can be expected, not all (or, in fact, very few) FCPP situations involve the fulfilment of the goals the missionaries declared, e.g. some end as early as the initial attempt to initiate conversation. The entire process, then, the general activity, including the individual phases by themselves or in combination with other phases, is defined by the missionaries as 'proselyting' and the data selection process reflects this.

Though the transcribed recordings make up the bulk of the examples in this article, data are also drawn from other parts of the ethnographic research: participant observation, field notes, semi-structured and 'interaction interviews' [Neustupný 2003] conducted with missionaries, and most importantly, written instructional materials supplied by the church. In this way, the micro-analysis in the following sections can be understood as culturally-contexted conversation analysis [Moerman 1988].

\section{Instructed actions}

The 'instructed' action is primarily a concept of ethnomethodology. It has been discussed by several authors in relation to one of EM's later directions and often related to actions on the basis of formal types of instruction materials such as maps, manuals, recipes, and guides [Livingston 1995; Garfinkel 2002; Lynch 2002; ten Have 2004]. Ten Have describes it as '...the local, each-time-again, embodied character of practical order-producing activities, conceived of as an achieved relationship between on the one hand descriptions and instructions and on the other hand the actual activities to which these descriptions and instructions refer'

\footnotetext{
${ }^{9}$ See item 14 of the list in Footnote 7.
} 
[ten Have 2004: 152]. Lynch [2002: 128-129] (citing Garfinkel) describes 'actions performed in accordance with instructions' as two-part actions, which is detailed by the following diagram:

\section{[Instructions] $\leftrightarrow$ [Lived course of action $\}$}

In the diagram, 'instructions' are any sort of formal ${ }^{10}$ instructions for doing an action, and 'lived course of action' is the actual course of 'lived work', of carrying out this action or actions. 'The arrow denotes the situated work of using the instructions, making out what they say, finding fault with them, re-reading them in the light of what is happening just now, and other contingent uses and readings.' [Lynch 2002: 129] This is not a one-directional relationship. Rather, it is a dialectic one - the instructions are continually modified on the basis of repeatedly doing the action. The process of continually modifying the proselyting process works in a similar way. This 'lived course of action' is also closely related to the setting in which the missionaries find themselves. As mentioned in the introduction to this study, the Mormon missions pride themselves in the claim that, as was often stated in the ethnographic research, 'we all teach the same thing'. Many of the manuals available to the missionaries are universal, written for any missionary serving in any country in the world, despite the fact that the missionaries who read them have very different experiences. The question that this study poses, then, is that of how these universal instructions translate into lived public proselyting encounters done in terms of talk. Furthermore, there is the question of what makes proselyting different from any other activities done through talk which involve the establishment of some sort of closer relationship between actors. The analysis to follow, then, involves instances of the lived course of action, a group of particular situations in talk. They all involve the following mutually elaborative, methodologically accomplished aspects of social order:

1. The local sequential order. The situations consist of individual sequences and adjacency pairs, and are also guided by the norms constitutive of action for the operation of these sequences.

2. The extended sequential order or the global organisation of the talk. In its missionary-envisioned ideal form, the proselyting encounter is a sequence of sequences that enable the introduction and maintenance of certain topics as well as the mutual categorisation of the interlocutors.

3. The topical order. One element that makes proselyting recognisable is the topic of God or faith. Proselyting situations begin in public between two strangers, and the transitions between topics must consider this fact. Relevant is the topical order as it revolves around the issue of religious faith, symbolised by the question 'Do you believe in God?'

10 'Formal' here may be seen as tangible instructions in writing with a specific 'instructional structure', as exemplified in the previous paragraph, yet I understand the term a bit more loosely, including the 'instructing' done between missionary companions. 
4. The categorial order. Prior to any verbal exchanges, the interlocutors have already categorised each other. The talk participants' mutual categorisation indicates what topics will be discussed, and, conversely, the topics that are discussed indicate the mutual categorisation that the talk participants are already doing. Relevant is the question of how, following the initiation of the encounter, the missionaries account for the fact that they have done so, and how the question of their identity relates to the activities they are performing.

Even if it were desirable, it would not be possible to easily tease apart either the elements of the diagram of instructed actions or the various types of order, which make up the 'layering' [Sacks 1992] of talk-in-interaction in proselyting encounters. The aim of a missionary over the two-year mission period, ultimately, is to move further and further away from the instructions, such that the process of proselyting, including contacting, becomes more and more natural, yet to be able to formulate the instructions in some way so that they might be passed on to a newer, less experienced missionary. In the following sections, I will use different types of data to illustrate these processes.

\section{Acting instructedly}

Though an LDS missionary may spend much of his or her life beforehand preparing to go on a mission, it is only when he attends the Missionary Training Center that he begins to receive any sort of step-by-step information - instruction on exactly how to do missionary work. Even then, before he has actually entered the mission field, he may even have heard stories from returned missionaries or read preparatory literature, yet much of the instruction he has received is vaguer in nature, e.g. 'talk to as many people as possible'. In language instruction classes, he may have been asked to plan out a foreign-language dialogue to use in certain situations. The materials he receives upon arriving at the mission site also contain sample dialogues. Some of these dialogues are even so specific as to contain suggestions for questions to ask in conversational openings. They are not as specific as, e.g., the scripts used in conducting telephone interviews [cf. Maynard et al. 2002]. Rather, they can be compared more closely to the materials used by psychotherapists [cf. Leudar et al. 2008], though psychotherapy training involves many years of formal study.

The missionary has the opportunity to watch his more experienced companion demonstrating 'doing' first-contact proselyting encounters, which, presumably, he is to be able to eventually emulate. Eventually, the new missionary has to do these encounters himself, initially purely on the basis of the 'instructions' he has received up to now. In observing and then doing FCPP situations over the two-year period, his 'documentary method of interpretation' [Garfinkel 1967; Heritage 1984] further develops his understanding of them. The documentary method of interpretation 'consists of treating an actual appearance as "the docu- 
ment of," as "pointing to," as "standing on behalf of" a presupposed underlying pattern. Not only is the underlying pattern derived from its individual documentary evidences, but the individual documentary evidences, in their turn, are interpreted on the basis of "what is known" about the underlying pattern. Each is used to elaborate the other.' [Garfinkel 1967: 78] The behaviour of a missionary's interlocutors in proselyting situations offers these underlying patterns, and when it deviates from them, these deviations are considered in his further sense-making practices and their utilisation in interaction. By the time a missionary has completed his mission, his understanding of how he has done proselyting, and, in fact, how to do proselyting, looks somewhat different than it did at the beginning. Doing proselyting is a process gradually refined, that is, it is comprised of the repetition of a sequence of actions which may be successful or unsuccessful at any point. It involves overcoming natural troubles which may occur, 'getting the hang' of missionary work in such a way that it can be passed on to a newer missionary.

Previous work on interactional activities which are learned through the practice of doing them over and over include that on the survey interview [Maynard et al. 2002]. Maynard and Schaeffer [2002], based on ethnographic research and analysis of telephone survey encounters, described a number of practices and devices involved in the instructed action of conducting a telephone interview. Research on surveys conducted on the basis of a pre-written script utilises the concept of 'tailoring' the script [Groves, Cialdini and Couper 1992; Couper and Groves 2002; Maynard and Schaeffer 2002]. Tailoring is done as a recruiting strategy, in anticipation of the fact that potential survey participants will refuse participation. In doing tailoring, the survey interviewers utilise contextual cues they have observed about the participants and constantly seek out new cues, such that they are able to 'quickly size up a situation to apply the appropriate persuasive messages' [Maynard et al. 2002: 33]. Maynard and Schaeffer [2002: 225] also refer to what is known as 'reviewing the script', meaning that the survey interviewer does not read the script verbatim, but rather uses it as a resource, puts it into his or her own words.

I will argue here that the major work involved for the missionaries in the FCPP situations involves this type of tailoring and script-reviewing, and show that most of their effort involves enacting these processes in relation to instructions in order to reach each relevant phase of the FCPP encounter, i.e. the opening phase, the identification and recognition phase, the transition to the topic of religion, and the solicitation of further contact. For some phases, the missionaries have access to more formal instructions, while for others, they rely more on the lived course of action. I will briefly exemplify some of the types of formal instructions the missionaries receive and then observe the ways in which the missionaries use them, how the processes of 'tailoring' and 'script-reviewing' look. For the purposes of what is referred to by the missionaries as 'contacting', instructions fall into two categories: (1) instructions for beginning conversations and (2) in- 
structions for soliciting further contact. In the data, most of the missionaries' contacting work concerned activities from the first category. In other words, it should be understood that most of the recorded FCPP situations involved interlocutors who were not interested in extended conversations in public, thus the encounters did not develop into intense discussions of religion, and, in fact, that the missionaries oriented themselves to the encounters as such.

The two categories of written instructions are largely taken from what the missionaries receive during their training period (which is geared more towards missionary work in general, all around the world, as opposed to in the Czech Republic in particular), and subsequently, upon their arrival at the mission site, in particular the local 'Czech Prague Missionary Handbook' (which is oriented specifically toward the country of the mission, though it is most likely inspired by work conducted around the world as well). On page C-7 of this handbook, there is a list of what are called 'Contacting approaches'. Some are very basic, some have a significant religious tone, others are oriented towards other topics. All are necessarily tailored in given FCPP situations, some on the basis of national or regional cultural aspects, others on the basis of the unfolding of individual encounters. Each type will now be briefly examined.

\section{Instructions for beginning conversations}

In this first category, the missionary materials contain two types of conversation-beginning themes - religious themes and what can be deemed 'local culture themes', this including language as an element of local culture. Some examples of the prescribed contacting approaches involving religion are the following:

\section{Example $1^{11}$}

'Prosím vás, můžeme mluvit s vámi na chvilku. Jsme misionáři...'

(English: Excuse me, can we speak with you for a little while. We're missionaries...")

'Můžu s vámi na chvilku mluvit? Veř́ite v Boha?' [Hold the B.O.M..$^{12}$ as if it's precious]

(English: Can I speak with you for a little while? Do you believe in God?)

[Introduce yourselves] 'Můžeme se s vámi [sic] sdělit poselství dnes?'

(English: Can we share a message with you today?)

'Máme jednu knížku pro vás, to je zdarma. Je to další svědectví o Ježíši Kristu.'

(We have a book for you, it's free. It's another testament of Jesus Christ.)

\footnotetext{
${ }_{11}$ All examples in this section are presented in the original Czech or Czech-English form (with the meta-commentary in English). They are reproduced as they were printed, i.e. with language errors in Czech. The translations which follow in parentheses are mine.

${ }^{12}$ Book of Mormon, the main teaching material used by the church in addition to the Bible.
} 
[Be sincere] 'My jsme tady [sic] abychom informovali lidi o nás.'

(English: We're here to inform people about us.)

[Introduction-make contact-smile] 'Můžu se vás na něco zeptat? Můžeme s vámi mluvit o Bohu, [sic] a o jeho plánu?'

(English: Can I ask you something? Can we speak to you about God and his plan?)

[Introduction-shake hands] 'My máme důležité poselství o Bohu a o Ježíši Kristu.'

(English: We have an important message about God and Jesus Christ.)

[Introduction-make eye contact] 'Máme důležité poselství pro vás o (Knize Mormon, Bohu, Ježíši Kristu). My víme [sic] že je to pravda a důležité pro nás i pro Vás.'

(English: We have an important message for you about (the Book of Mormon, God, Jesus Christ). We know it's true and important for us and for you.)

[Introduce yourself] 'Zajímá mě to, čemu věří lidé tady v ___. Jste věřící?'

(English: I'm interested in what people here in believe. Are you a believer?")

It can be observed here that in addition to the religious theme, in many cases, there are other, separately bracketed instructions which do not take the form of a script, but rather, of descriptions of actions, which, ultimately, could also be scripted themselves. ${ }^{13}$ This is important because the data reveal that the immediate religious self-categorisation (as we will see in the analysis of the actual categorisation work in the examples below) in these scripted statements is not a practice commonly done by the missionaries. The missionaries reported that they did not use the opening lines with the religious element, and the research using the recorded data confirms this. The early mention of religion seems to be associated with perceived rejection, and it is apparently more useful to get into a tailored conversation with the person before mentioning it.

Local culture themes, thus, may be deemed more appropriate. However, they are also not without the need for tailoring. The following is the most common local culture approach:

\section{Example 2}

37. A good way to begin talking to someone while contacting is to ask them what a certain Czech word means. You can use some of these questions:

'Jaký je rozdíl mezi slovy ___ a__ ? Don't forget adding [sic] the word slovy, it helps clear up that you are asking about those specific words. Also, don't use Co je rozdíl... Co znamená slovo__? Use it when you want to know what a specific word means (for example, on a bus, you can use it to ask someone what a word on an advertisement flyer means).'

(From the Czech Prague missionary handbook).

\footnotetext{
${ }^{13}$ The form of the data (audio recordings), however, does provide some limitation to this, even though there may be some indication of the most apparent actions from the ethnographic field notes.
} 
This example, involving finding two seemingly synonymous words, approaching someone in public and asking 'what is the difference between the words...' (Jaký je rozdíl mezi slovy...) indirectly instructs the missionaries to draw as much attention as possible to the fact that they are learners of Czech or non-native speakers of $\mathrm{Czech}$, which are categories which can be connected to the topical order of the encounter. This fact is reflected by the missionaries as well. As one stated in an interview:

\section{Example 3}

'...it depends like I don't know on the situation sometimes like (.) um you usually sit down next to someone? you just like start talking about I don't know ask them about the weather,... about some whatever like,... ask them a question like- when I was (.) a younger missionary like when I was (.) first in the country asking questions about the language,... is a big one just like,...you know like I heard this like what does it mean? and they're like oh (.)why are you here? (.) like you're an american and you're trying to learn czech? alright...well uh: (.) so that's how I got (.) that's like (.) um like for english classes, like oh I love english classes because (.) we teach them english and they wanna know why we're doing it for free:... why we're trying to why we know czech...like why are you here (.) and like you make a lot of friends like (..) they wanna know like what you're doin and stuff so like that's really good. (..) I don't know just (.) trying (.) to be friends with people.'

Problems in initiating conversation which occur in the course of the missionaries' lived work often develop gradually along such lines, as in the following example.

\section{Example $4^{14}$}

1. M1: uh excuse me could we speak with you?

2. C32: I'm in a hurry

3. M1: ((fast)) well we're in a hurry too we're just here as

4. volunteers missionaries from the church of jesus

5. christ, and we offer several uhm services here,

6. for example we teach free english I don't know if you

7. happen to know english or if you know someone

8. C32: I know a little ((laughs))

9. M1: yeah? are you able to speak?

10. C32: I am

11. M1: yeah? ((slowly, in English)) what is your name?

${ }_{14}$ The original transcripts of examples 4, 5, 6, 8, 9, and 10 in Czech (with the exceptions of turns or portions of turns marked 'in English' can be found in Appendix 3 at the end of this text. All translations into English are mine. 
12. C32: ((English) ) my name is ladislava ${ }^{15}$

13. M1: ((English) $)$ d- well nice to meet you.

The opening 'excuse me, could we speak with you?' (line 1) can be found both in the written instructions from the Czech Prague missionary handbook and in this example from the naturally occurring data. It was also the opening generally mentioned by the missionaries when interviews were initially conducted with them and they were asked to explicitly describe their contacting interactions to the best of their ability. The response by C 32 was also commonly mentioned in the interviews. ${ }^{16} \mathrm{M} 1{ }^{\prime} \mathrm{s}^{17}$ reaction beginning in line 3 displays his competence as a missionary, suggesting that the quickness and content of reaction - immediate self-identification, revealing the fact that the missionaries offer several services, and then the question of whether C32 speaks English, thus making her accountable for an answer - reflects his experience.

Problems in the phase of identification and recognition help to illuminate the missionaries' use of the documentary method of interpretation. The missionaries are able to gradually ascertain which categories may be more or less familiar, vague, agreeable, or disagreeable to potential interlocutors. The approach, then, is typified by the following example:

\section{Example 5}

1. M1: hello ma'am

2. C13: hello

3. T: hello

4. $((\ldots))$

5. M1: do you know us?

6. C13: I don't.

7. M1: you don't

${ }_{15}$ All names and identifying details have been changed in order to protect the participants' anonymity.

${ }_{16}$ This was revealed in a series of interaction interviews [see Sherman 2006] with missionaries conducted prior to the greater part of the fieldwork, as in the following example:

14. M4: uh huh some people don't want to talk to us,

15. T: $\mathrm{mm} \mathrm{hmm}$

16. M4: but like they say prosím vás or like ( ) I don't know they just

17. don't want to talk to us=

18. M5: =spěchám $=$

19. M4: =and so but I talked to one (.) girl who was really really nice...

${ }_{17}$ Missionary speakers in the FCPP interactions are marked as 'M1', 'M2', and 'M3'. Other missionaries, i.e. those appearing in other transcripts, e.g. from interviews, are also marked numerically in this way. Czech speakers are numbered chronologically as C1-C43. The researcher is marked as ' $\mathrm{T}$ '. 


\section{C13: I don't but}

9. M1: you hear our my accent right? [yeah ((laughs))]

10. C13: [you're probably foreigners]

11. M1: we're we're from america

12. C13: aha students?

13. M1: [what?]

14. M3: [uuh no]

15. M1: I'm from california

16. C13: aha

17. M1: we're here as volunteers

18. C13: $\mathrm{mm} \mathrm{hmm}$

19. M1: uh (.) do you happen to speak english?

20. C13: unfortunately no

21. M1: no?

22. C13: unfortunately my whole family does but I don't

23. ((laughter))

24. M1: yeah? you know what? maybe you can (.) (come to) (.) [us] ((hands

25. her a flyer))

26. C13:

27. M1: we teach (.) free english here

[well thank you]

Participants use categories widely to establish 'recognisability' in the initial phases of interaction, in the process of identification and recognition, in handling the question of who is speaking to whom. Sacks' [1992] economy rule tells us that a single category is sufficient for reference to a person, and we thus ask the question of 'Why that category now?' Yet as Jayyusi [1984: 135] points out: 'One categorization, chosen for its self-explicating relevance, may perform the practical task at hand for which a category selection is required and by which that particular selection is warranted. This does not mean, however, that in every such case one (and this) categorization is the only one relevantly available.' Each category the missionaries and their interlocutors use in FCPP situations is relevantly available at a different point in the talk, and the use of some categories subsequently makes other categories relevantly available.

This is often a question of gradation, or, as Jayyusi [1984: 38] calls it 'hierarchy or relevance or consequence'. In this case, there is a continually developing idea (based on each missionary's past experience) of which categories may be more or less familiar, vague, agreeable, or disagreeable to potential interlocutors. The missionaries' self-identification appears generally to be one of beginning with a category which is most vague or general and gradually using categories which are more specific (volunteers $\rightarrow$ English teachers) as well as moving from a category which is perceived to be more agreeable to one that is less so (English 
teachers, Americans $\rightarrow$ missionaries), but most of all, moving from a category which is perceived to be more familiar to one which is perceived to be less familiar (volunteers, English teachers, Americans $\rightarrow$ missionaries, Mormons).

This gradual development can be seen in the example above. There are five categories used directly: three by the missionaries to describe themselves, and two offered by their interlocutor. The encounter begins with the missionaries practicing their Czech with one another in public while walking along a sidewalk. A woman walking next to them hears them and turns to look at them. One missionary subsequently greets her and she returns the greeting. It is unclear as to what should follow, hence the longer pause before the next turn, marking a transition relevant point [Sacks, Schegloff and Jefferson 1974]. The question remains - why has the woman stopped to observe the missionaries? One possibility is that she might know them. The question 'do you know us?' is put forth, and the woman answers negatively, but conditionally 'I don't, but...' (line 8). She does not know them personally. But she has reacted to something they were doing, which she does not state. One possible 'head-turning' activity, speaking Czech with an accent, is identified by missionary M1. This leads to the use of the first category - foreigners (line 10). Foreigners are the people who speak Czech with an accent, thus the people who speak Czech with an accent belong to the ethno-category of foreigners or non-Czechs ${ }^{18}$. After the 'foreign' origin of the missionaries is confirmed, the need for the further specification of this category arises, and another is offered. That is, we must pose the question of: in the given city where the research took place, into which further categories can 'foreigners' be grouped? The ethnographic research revealed that the given city contained a university faculty which offered a programme of study in English, and the missionaries themselves observed that most of the other foreigners with whom they came into contact were students at this faculty.

Upon answering the question of whether they are students negatively (line 14), the missionaries then become accountable for explaining what, in fact, they are if not students. ${ }^{19}$ The next category offered by M1 is that of 'volunteers' (line 17). But as we will see, 'volunteers' is what might be understood as an 'incomplete category'. Activities which are bound to 'volunteer' include doing something without being paid for it, and doing something for what one considers a good cause. It could be argued that stating that one is a volunteer in the context of, e.g. walking into a soup kitchen and introducing oneself to the head chef, or arriving at the scene of a natural disaster, would not make the speaker accountable for explaining what kind of work he or she does or wants to do. But in a situation where there is no apparent 'cause' to be attended to, 'volunteer'

\footnotetext{
${ }^{18}$ See Nekvapil [2000] for an examination of the non-self-evident relationships between language and ethnicity.

${ }^{19}$ See also Watson [1997] for an analysis of the relationships between sequential and categorial order.
} 
could be seen as a 'hedging' or a 'mitigating' category - a category used as a predecessor to a further category, to delay a direct explanation of an individual's activities.

As is observable from this example, how the missionaries explain 'who we are and what we do' to their interlocutors is the first step in establishing what kind of relational pair the interaction participants form, may have formed in the past, or can form in the future. Thus, it is necessary to evaluate the categories used to describe the interlocutors, which can correspond to those already used in the missionaries' self-identification. The task at hand is for the interlocutors to collaborate to determine whether or not a pair of categories exists on the basis of which the interaction can continue, whether the two categories have any further activities in which they can (or are allowed to) engage in together. As Sacks [1992] has pointed out, stranger-stranger is not sufficient. That is, these sets of pairs may be used by the missionaries to distinguish between whom to address and whom not to address, whom to offer which services, which order of topics to use, and to what degree to prolong the conversation. In doing all of this, there is the constant expectation by the missionaries that each phase of the interaction may be met with resistance, so the they must avoid the categorising of themselves and their interlocutors in a way that might place them in the oppositional relation of 'us' and 'them', e.g. as 'believers' and 'non-believers'. ${ }^{20}$

All of these categories, as we can see, still manage, for the most part, to remain clear of the topic of faith. There is one more category, that of 'missionary', which cannot be ignored in the context of first-contact situations and which generally appears to be used in two slots in conversation. The first of these slots occurs initially, where the category of 'volunteer' might alternatively be used, preceding the 'listing' of things the missionaries do (model: we are missionaries and we do this, this and this). Later, it may be used to precede information of a religious nature, when another category has been chosen as the initial introductory category (model: we are volunteers/Americans, and we do this and this, and because we are missionaries, we also do this). Given the fact that these interactions are taking place in a 'foreign culture', there is no slot for the identification of religious category membership in the earliest stages of interaction, given that many interlocutors may not be familiar with the Mormon faith in the first place.

The use of categories in this initial phase, as we can see, serves as a negotiation activity in which a specific pair of categories is the goal - that of 'missionary - investigator'. ${ }^{21}$ The interactive path taken toward this goal involves transitioning to the topic of religion, as in the following example.

${ }^{20}$ This understanding of strategic category use in (Czech) religious discourse was first put forth by Havlík [2009] in his analysis of Christian sermons.

${ }^{21}$ This is the term used by the missionaries to indicate an individual interested in joining the church. 


\section{Example 6}

35. M1: and that's one thing we do here

36. C34: $\mathrm{mm} \mathrm{hmm}$

37. M1: and another thing we teach a course on how to stop smoking,

38. C34: $\mathrm{mm}$ hmm well so I don't smoke ((laughs))

39. M1: well alright you don't have that problem ((laughs))

40. C34: okay.

41. M1: and the last thing?

42. C34: no

43. M1: I already spoke a bit about it that we're here as missionaries but,

44. I don't know if you've heard of us? or if you're a believer at all?

As mentioned above, missionary scripts tend to move into the religious discourse relatively quickly. The missionaries must tailor them so that the topic of religion is introduced more gradually, beginning with a missionary stating the 'list' of activities that he and his companions engage in. Here, we see 'the list' described as such in its entirety. This excerpt has been preceded by M1's offer of English lessons. Line 35 can be viewed as a 'partial report' [Button and Casey 1985], as 'one thing we do', indicating that there are more items on the list to follow, that the 'mentionables' 22 are yet to be exhausted. Line 37, on the other hand, does not necessarily have a 'partial' nature to it. From the perspective of C34, it could very well be the final item on the list, and line 38 is thus a 'potential pre-closing' [Schegloff and Sacks 1973]. Thus M1 is then obliged to indicate that he is not ready to close the interaction. M1 requests the opportunity to introduce another topic (which he indicates is a final one, which serves to mitigate the fact that he is taking up C34's time). The topic introduced in line 41 is actually a recycled one and the move from the speaker's self-categorisation as a missionary is then transitioned into the question of whether C34 is a 'believer'.

One topical phenomenon this example reveals is that the missionaries selfidentifications as either 'missionaries' or 'Mormons', when not immediately followed by further mention of predicates which are bound to faith, for example, in an initial identification and recognition sequence, cannot be understood as a sufficient method of topic nomination for the topic of faith. This is due to the fact that these identities are not relevant to both participants until both participants are consciously and actively involved in a discussion of faith.

Once this discussion ensues, or even if it does not, there remains one specific task for the missionaries, to attempt to make further contact with their interlocutors. This key task is also commonly the subject of instructions.

22 'Conversationalists, then, can have mentionables they do not want to put in first topic position, and there are ways of talking past first topic position without putting them in.' [Schegloff and Sacks 1973: 301] 


\section{Instructions for soliciting further contact}

In summarising what the missionaries do in their attempts to ensure that an FCPP situation will not be the last time they and their interlocutors meet, it is relevant to look back to the Czech Prague mission handbook (C-33), which notes, among others, four principles of 'friendshipping' concerning obtaining further contact:

\section{Example 7}

'1. It is generally true that the longer the conversation we have with a friend, the more likely we will obtain a phone number to call.

2. It is generally better to ask 'Can we call you sometime?' than it is to ask outright for a phone number, 'Could we have your phone number?' If they consent we can pull out a pen and notebook and ask, 'What number would be best to call?'

3. It is always best to try and obtain a phone number from them before offering them a piece of literature with our number on it.

4. It is a folly to imagine people will be willing to give us a phone number before some level of trust has been established.'

These instructions are very commonly played out in the interactions. Problems in initiating further contact are detailed in the following example.

\section{Example 8}

170. M1: and what do you believe?

171. C33: uh: more like uh like- I'm not a total believer but (.) more like

172. (.) buddhist things and stuff like that

173. M1: yeah? yeah? I've heard something about that like

174. C33: $\mathrm{mm} \mathrm{hmm}$

175. M1: as I've spoken with a lot of people? about religion and

176. everything it it interests me like I was in lebedice?

177. C33: $\mathrm{mm} \mathrm{hmm}$

178. M1: and there was a hin- hinduist? how do you say it? is it right?

179. C33: $\mathrm{mm} \mathrm{hmm} \mathrm{mm}$ hmm $\mathrm{mm}$ hmm

180. M1: yeah? they have interesting (.) like (.) culture and

181. C33: $\mathrm{mm} \mathrm{hmm}$

182. M1: and religion (.) and would you also like to hear us our like(.)view?

183. C33: why not?

184. M1: why not? so that's great

185. C33: why not why not? uh:: (.) so here it's enough you're there

186. every tuesday?

187. M1: $\mathrm{mm} \mathrm{hmm}$ 
188. C33: it's enough to come right?

189. M1: $\mathrm{mm} \mathrm{hmm}$, but, what we normally do there

190. C33: $\mathrm{mm} \mathrm{hmm}$

191. M1: is we have $\mathrm{m}$ - we don't live there we

192. C33: $\mathrm{mm} \mathrm{hmm}$

193. M1: do you know the stop květen?

194. C33: $\mathrm{mm} \mathrm{hmm}$

195. M1: we live there

196. C33: yes

197. M1: and we have like meetings with people

198. C33: $\mathrm{mm} \mathrm{hmm}$

199. M1: like thr- (.) or during the week

200. C33: $\mathrm{mm} \mathrm{hmm}$

201. M1: and could I like ring you? when we have time? this like this

202. week I could call you we can agree on a time?

203. C33: we can

204. M1: well great. we're modern missionaries ((laughter)) I like saying

205. that oops (.) what's your number?

((7 lines omitted, C33 provides number))

213. M1: great.

In this encounter, all of the above-mentioned goals occur: prolonging the conversation, asking for a phone number, and obtaining a phone number rather than providing a contact to oneself. All of these goals are components of the final item, 'establishing trust'. In terms of 'prolonging the conversation', M1 has approached C33 on a public square and this point in the interaction, the extensive list of activities that the missionaries do has been gradually detailed. In the course of this, the topic of religion has surfaced, and it is revealed that C33 has some religious orientation, but not a Christian one. After a period of negotiating C33's religious beliefs, M1 transitions to an offer - would you like to hear a new view on faith? (line 182). C33's positive response, however, is followed (repeatedly, in lines 185-186 and 188) by the suggestion that 'it's enough to come on Tuesday'. In other words, C33 is proposing that he himself will make the next move in the future interactions between himself and M1, which is similar to taking M1's phone number and saying that he will call him. M1 therefore must do more work to ask for and obtain C33's phone number, as C33's suggestion is not satisfactory.

Through the extended descriptive sequence in lines 189-199, M1 indicates that C33's coming to English class on Tuesdays was not exactly what he had in mind when he made the offer in line 182. This serves as a both a pre-proposal account and a post-proposal expansion - an explanation of what the initial offer in line 182 actually entailed as well as a set-up for the proposal that ensues in 
lines 200-202. M1 then proposes that he could 'ring ${ }^{23}$ C33 and they could set up a concrete time to meet. There are two parts to this turn. The first is the proposal itself ('can I ring you?'), and the second is the account or post-proposal expansion ('when we have time next week we can call you and set up a time'). C33 gives M1 the number and M1 rings him. Further contact information has thus been gained by M1. This case involves a bargaining sequence [Arminen 2005: 175], throughout which M1's requests, offers, and proposals have become more and more specific until all of the goals have been reached.

In sum, many of the interactional problems encountered by the missionary involve observing the principle of 'Do not bother people', which is declared by the missionaries in interviews as well. As concerns instructions, the opening phase is not dealt with in detail in instructions, this is where there is a lot of room for spontaneity, and, in fact, the missionaries are left to observe general principles of politeness. In the identification and recognition phase, there is a clear difference between the written instructions and the lived course of action, in that the instructions contain near-immediate self-identification, but the actual interactions nearly never allow for such a practice. The third phase, the transition to the topic of religion, is presented earlier in instructions, but occurs later in reality - what the instructions do not count on is this transition being a difficult one. Finally, the instructions consider the solicitation of further contact as a negative politeness strategy [cf. Brown and Levinson 1987], as it is often played out in the interactions. There is a specific cultural and visual element to the individual phases as well - there is the possibility that, based on the missionaries' appearance, their interlocutors may recognise them and know what their communicative goals are, thus giving the identification and recognition phase another, briefer form less based on the gradual mentioning of categories described above, and also changing the character of the transition to the topic of religion.

In this section, I have pointed to some of the relationships between written instructions and the repeated day-to-day problems encountered in proselyting encounters, which usually involves the tailoring of the instructions to a certain degree. In the next section, I will demonstrate the aspect of trans-situationality which is inherent in the process of doing instructed actions. I will show how the tailoring developed in one situation is utilised by the same missionary in further situations, based on the tailoring 'resources' (otherwise known as the 'lived course of action' by Lynch) that are acquired in the first situation. In other

\footnotetext{
${ }^{23}$ In Czech, the term 'prozvonit' is used to refer to the practice of creating a 'summons' (dialling a mobile phone number) without the expectation that this summons will be answered, or, in fact, the hanging up of the phone before the other person has a chance to answer. This serves several purposes: either it functions in the place of other types of summons (e.g. a doorbell), as an indication that the caller does not have credit to pay for the call and expects the 'called' to call him back (it is only the caller who pays for the call in the Czech mobile phone system), or, finally, it functions as a way to put one's phone number into the memory of the other person's phone or to 'check' that the phone number one has been given is the correct one. These calls are also known as 'boom calls' [Castells et al. 2007].
} 
words, the missionaries, in interacting with various people, acquire the ability to recognise and utilise ever more contextual cues, to implement what Maynard and Schaeffer [2002: 229] call a 'device' or 'a form that an interviewer uses across contexts, again and again'.

\section{Processes of tailoring across individual interactions: the case of presenting prayer}

During the course of the data collection, a series of interactions which were topically interrelated was recorded (by chance) over the course of a week. All of them are taken from 'street display situations' (as described above), and through them, I will attempt to demonstrate the effect of the 'lived course of action' on M1's interactional competence. In the first interaction of this series, M1 approached a teenage boy on a public square.

\section{Example 9}

79. M1: because we believe that these things? like: faith can help us

80. in our lives (.) defin- you loo- you look- dyeh- you look like

81. a athlete. are you an athlete?

82. C9: I play soccer

83. M1: yeah?

84. C9: and (.) I bet ((laughs))

85. M1: ((laughs)) and maybe like before a match, like: when it was hard

86. or the other team was really good

87. C9: I always when I need when (I bet) always god make (him score

88. the goal)

89. M1: exactly ((laughs))

90. C9: yesterday I went to the bathroom I prayed and it helped

91. M1: really?

92. C9: my dad did it once too,

93. M1: uh huh?

94. C9: [in his case he needed some money]

95. M1: [and did it work?]

96. C9: well yeah

97. M1: so you see

98. C9: but it has to be in the bathroom

99. ((laughter))

100. M1: so let's go let's go let's go to the WC ((laughs))

101. C9: but once I overdid it somehow before the match (.) but (.)

102. it didn't work out hi ((to C10, who is arriving)) 
103. C10: hi

104. C9: hey come over here

105. C10: yeah?

106. C9: this guy says that when you pray your ticket will win ((laughter))

107. C10: yeah

((10 lines omitted $))$

118. M1: oh my g- (.) exactly. my gosh. so well? so you see like you're

119. already like half believer right? like if you pray sometimes you

120. probably believe something's there right

121. C9: well: (.) but like (without) realising that [that's what

122. it actually is]

The global sequential order of the conversation is typical for the FCPP encounters, in that following the opening sequence there is the identification and recognition sequence [Schegloff 1979]. M1 has initiated the conversation, identified himself and introduced the topic of religion, as 'the main thing we do', posed the question to C9 - does he believe in God? C9's first response has been a negative one. What follows is what appears to be M1's spontaneous solution - in the interest of talking about people's hobbies, an example of a solution to a common problem that missionaries face - what to do if their interlocutors state that they do not believe in God, or otherwise express negative reactions to the missionaries' purpose of stay in the Czech Republic. The ultimate outcome of this is the confirming statement by $\mathrm{C} 1$ in lines 121-122 that he has been a believer for some time without actually realising it.

The ethnographic research revealed that M1, who at the time was participating in the group proselyting activity known as 'street display' described above on a public square, upon the conclusion of the encounter, returned to the group of his fellow missionaries who were singing, described the encounter, and evaluated positively the fact that he had spontaneously used a sports analogy to point out to his interlocutor that he had engaged in a religious practice. We can therefore understand that C1's statement in lines 121-122 represents the fulfilment of one of M1's interactive goals.

About a week later, M1 was again engaged in a 'street display' on the same square and encountered two teenage boys. Upon reaching the exact same problematic spot in the interaction (the interlocutor declaring that he or she is not a believer), M1 attempts to make use of the same analogy, as detailed in the following excerpt.

\section{Example 10}

81. M1: ((laughs)) well, we have a message about jesus christ (brief-

82. briefly) uhm because there are (certainly) a lot of churches even

83. though you're not a believer 
84. C28: $\mathrm{mm}$

85. M1: maybe (.) like every one of us (.) has had experience with

86. believing maybe(.)you you look like an athlete(.)are you an athlete?

87. C28: yeah:

88. M1: you too? (.) no:?

89. C27: not really

90. M1: and like when you had like a big match (.) did you pray?

91. C27: ah I just do snowboarding

92. M1: oh yeah yeah (.) [aha that's how it is]

93. C27: [( )]

94. M1: yeah? I snowboard too but in america not here((laughs)) he- here

95. but (.) like I've spoken with a lot of people and a lot of people

96. said they weren't believers(.) but they at least believe in energy

97. or maybe before a big match they prayed for help or something

98. C28: so in that case they're believers

99. M1: yeah? but even even if like the people? (.) like said before that

100. they weren't believers and I said and what about before a match or

101. something? he said oh yeah: right ((laughs))

102. C27: then in that case they don't know what they're saying

It may be tempting to observe that this particular case was an 'unsuccessful' one, in that M1's interlocutors were not ultimately convinced by M1'a prayer analogy in his efforts to do what Maynard and Schaeffer [2002] call 'refusal conversion'. The interaction continued on with M1 attempting to discuss the topic of religion further and subsequently initiating further contact by inviting his interlocutors to attend the free English classes or to come meet with him to discuss these various topics further. This is met with the reiteration by the interlocutors that they are in fact not believers and that further contact would not be beneficial to them, added to the fact that they live in a special dorm for secondary school students where their presence is carefully monitored, and they thus are not free to go out whenever they choose. However, upon returning home in the evening, not only does M1 register having talked to the two teenagers as a work activity (i.e. in his work journal which the missionaries are required to keep), but he also reflects on the situation for the purpose of future interactions. The association of proselyting or contacting 'work' with some sort of instant success belongs to the lay understanding of it as opposed to that of the missionaries themselves. 


\section{Ethnomethodology and conceptualising proselyting as the object of study}

This study has introduced the analysis of a proselyting encounter as a members' phenomenon which occurs interactionally, turn-by-turn in talk. The lay understanding of proselyting or proselytising is that it involves inducing others to convert to one's religious faith. However, in many of the FCPP situations I have presented here, it is observable, in fact, how little religion is actually involved. What I have attempted to show in this study is the detailed work that it takes to 'get to God' and subsequently initiate a dialogue, and hopefully, some type of relationship, when proselyting in another culture, the work it takes within individual interactions, produced, at least in part, on the basis of various types of instructions.

Missionaries employ the documentary method of interpretation, encounter by encounter. They do the whole of the FCPP situation, and their interlocutors collaborate (or do not collaborate) in various ways. The ways in which people collaborate guide the missionaries in their future interactions, as there are patterns in people's responses. These patterns are also demonstrated in the way the missionaries react to the various types of responses. In this way, they can be uncovered by the researcher both through the recordings of the interactions and through interviews, as well as through ethnographic research which involves noting the missionaries' pre- and post-interaction reflections.

There are two methodological implications which result from this study. The first of these concerns the fact that naturally-occurring talk is presented as the most important focus of the analysis in this study, but is not isolated from the context in which it was collected for the purposes of analysis. As mentioned above, we can call the CA being done here 'culturally-contexted conversation analysis', a potential element in ethnographic research introduced by Moerman [1988]. ${ }^{24}$ This involves, first of all, the notion of culture not as 'a uniformly owned property of a discrete society', but as 'a set - perhaps a system - of principles of interpretation, together with the products of that system. In this sense, the materials of all conversation analysis are inextricably cultured' [Moerman 1988: 4]. This study has proceeded in a similar direction without originally intending to do so. At the outset of the study, it was not clear that conversation analysis would be the main analytical tool. Traditional ethnographic research techniques, such as participant observation, field notes, and the collection of in-group materials were used in order to determine an appropriate topic. Only after these techniques were utilised was the ultimate topic for the analysis selected. In other words, this is a targeted study which still managed to involve 'unmotivated looking' [Psathas 1995]. This study also combines CA with other EM-type approaches, or, in other words, uses a number of approaches to study a phenomenon which could be

${ }^{24}$ For a more extensive discussion of the question of the relevant context, see Dupret and Ferrie [2008]. 
limited to CA alone. It is a contribution to the study of actions done through talk which are in some way instructed. In this way, it expands further on the work on 'standardisation and tacit knowledge' done by Maynard et al. [2002], and invites further such expansion.

\section{Concluding remarks - relating proselyting to other types of actions}

This study has demonstrated two points. One is that, as opposed to one lay opinion that religious missionaries simply recite learned passages and phrases in doing their proselyting work, their activities in fact involve complex sequences of communicative work which require the utilisation of experience, tacit knowledge, and creativity. The other is that, while it is possible to flesh out and describe a clear sequence of phases in FCPP encounters which, from the outsider's perspective, constitute proselyting, there is little which differentiates it from a broad range of other types of activities involving talk. Yet at the same time it is very quickly recognised by the missionaries' interlocutors as proselyting. In this vein, another activity has been described as well - the practice of resistance, to which these two main findings also apply. The interlocutors, having gradually perceived the emerging proselyting character of the missionary talk, orient their reactions based on a method of interpretation of the nature of the talk which documents its religious nature.

People build relationships with strangers in public for a number of reasons and they do so through talk. In the building of such relationships, the motives of one party are often very different from those of the other. Proselyting situations are the initial sequences of a longer series of talk which involves one person attempting to get another to re-categorise in relation to the first person's church. This study has specified the types of order to which both actors orient in these situations. The discussion has shown how they demonstrate these orientations through the use of natural language, as 'members' in the sense of Garfinkel [1967]. The argument has been that a seemingly specific activity involves the orientation to the same sets of order as any other activity, which is in fact quite normal for any social actor, and that proselyting, though seemingly defined by its sensitive 'main topic' of religion, is thus not essentially different from any other talk-based activity. Furthermore, it has been demonstrated that the "learned" nature of proselyting involves learning to utilise the interactional sense-making capabilities that individuals already possess. Harold Garfinkel, in describing the work of jurors, noted the following:

As a person underwent the process of 'becoming a juror', the rules of daily life were modified. It is our impression, however, that the person who changed a great deal, changed as much as 5 per cent in the manner of making his decisions. A person is 95 per cent juror before he comes near the court. [Garfinkel 1967: 110] 
Much has been written on the subject of preparation for activities such as missions, as well as on the 'life-changing' phases that they are. As social actors, most of what the missionaries need to engage in talk in doing their work is, similarly, something they already possess - the sense of order and organisation, and the ability to both produce and interpret this order and organisation in and through talk.

TAMAH SHERMAn completed her BA at Northwestern University and her MA and PhD at the Faculty of Arts, Charles University in Prague, where she continues to work as a researcher. Her work utilises a range of frameworks, including ethnomethodology, conversation analysis and language management, in the ethnographic analysis of multilingual contexts in the Czech Republic, most recently as a part of the European FP6 project LINEE (Languages in a Network of European Excellence).

\section{References}

Arminen, Ilkka. 2005. Institutional Interaction - Studies of Talk at Work. Ashgate: Aldershot. Brown, Penelope and Stephen C. Levinson. 1987. Politeness: Some Universals in Language Usage. Cambridge: Cambridge University Press.

Button, Graham and Neil Casey. 1985. 'Topic Nomination and Pursuit.' Human Studies 9: 355.

Capps, Lisa and Elinor Ochs. 2002. 'Cultivating Prayer.' Pp. 39-55 in The Language of Turn and Sequence, edited by C. Ford, B. Fox and S. Thompson. Oxford: Oxford University Press.

Castells, Manuel, Mireia Fernandez-Ardevol, Jack Linchuan Qiu and Araba Sey. 2007. Mobile Communication and Society: A Global Perspective. Cambridge, MA: MIT Press.

Cornwall, Marie, Tim B. Heaton and Lawrence A. Young (eds.). 2001. Contemporary Mormonism: Social Science Perspectives. Urbana, IL: University of Illinois Press.

Couper, M. P. and R. M. Groves. 2002. 'Introductory Interactions in Telephone Surveys and Nonresponse.' Pp. 161-177 in Standardization and Tacit Knowledge. Interaction and Practice in the Survey Interview, edited by D. Maynard, H. Houtkoop-Steenstra, N. C. Schaeffer and J. van der Zouwen. New York: John Wiley.

Dupret, Baudouin and Jean-Noel Ferrie. 2008. 'Legislating at the Shopfloor Level: Background Knowledge and Relevant Context of Parliamentary Debates.' Journal of Pragmatics 40 (5): 960-978.

Francis, David W. and Stephen Hester. 2004. An Invitation to Ethnomethodology: Language, Society and Interaction. London: Sage.

Garfinkel, Harold. 1967. Studies in Ethnomethodology. Englewood Cliffs, NJ: Prentice-Hall.

Garfinkel, Harold. 2002. Ethnomethodology's Program: Working Out Durkheim's Aphorism. Lanham, MD: Rowman \& Littlefield Publishers, Inc.

Goffman, Erving. 1963. Behavior in Public Places: Notes on the Social Organization of Gatherings. New York: The Free Press.

Groves, R. M., R. B. Cialdini and M. P. Couper. 1992. 'Understanding the Decision to Participate in a Survey.' Public Opinion Quarterly 56 (4): 475-495. 
Have, Paul ten. 2004. Understanding Qualitative Research and Ethnomethodology. London: Sage.

Havlik, Martin. 2009. ‘Diskurzní praktiky křest́anských kazatelů při konstituování standardního relačního páru "my" - "oni".' (Discursive Practices of Christian Preachers in the Constitution of the Standardised Relational Pair 'Us' - 'Them') Slovo a slovesnost 70 (2): 83-99.

Heritage, John. 1984. Garfinkel and Ethnomethodology. Cambridge: Polity Press.

Jayyusi, Lena. 1984. Categorization and the Moral Order. Boston, MA: Routledge \& Kegan Paul.

Knowlton, David. 2001. 'Gringo, Jeringo: Anglo Mormon Missionary Culture in Bolivia'. Pp. 218-236 in Contemporary Mormonism: Social Science Perspectives, edited by M. Cornwall, T. B. Heaton, and L. A. Young. Urbana and Chicago, IL: University of Illinois Press.

Lehtinen, Esa. 2005. 'Achieved Similarity: Describing Experience in Seventh-day Adventist Bible Study.' Text 25: 341-371.

Lehtinen, Esa. 2009. 'Conversation Analysis and Religion: Practices of Talking about Bible Texts in Seventh-day Adventist Bible Study.' Religion 39: 233-247.

Leudar, Ivan, Wes Sharrock, Shirley Truckle, Thomas Colombino, Jacqueline Hayes and Kevin Booth. 2008. 'Conversation of Emotions: On Turning Play into Psychoanalytic psychotherapy.' Pp. 152-172 in Conversation Analysis and Psychotherapy, edited by A. Peräkylä, C. Antaki, S. Vehviläinen and I. Leudar. Cambridge: Cambridge University Press.

Liberman, Kenneth. 2004. Dialectical Practice in Tibetan Philosophical Culture: An Ethnomethodological Inquiry into Formal Reasoning. Lanham, MD: Rowman \& Littlefield.

Livingston, Eric 1995. An Anthropology of Reading. Bloomington, IN: Indiana University Press.

Llewellyn, Nick and Robin Burrow. 2008. 'Streetwise Sales and the Social Order of City Streets.' The British Journal of Sociology 59: 561-583.

Lynch, Michael. 2002. 'The Living Text: Written Instructions and Situated Actions in Telephone Surveys.' Pp. 125-150 in Standardization and Tacit Knowledge. Interaction and Practice in the Survey Interview, edited by D. W. Maynard, H. Houtkoop-Steenstra, N. C. Schaeffer and J. van der Zouwen. New York: John Wiley.

Maynard, Douglas W. and Nora Cate Schaeffer. 2002. 'Refusal Conversion and Tailoring.' Pp. 219-239 in Standardization and Tacit Knowledge. Interaction and Practice in the Survey Interview, edited by D. W. Maynard, H. Houtkoop-Steenstra, N. C. Schaeffer and J. van der Zouwen. New York: John Wiley.

Maynard, Douglas W., Hanneke Houtkoop-Steenstra, Nora Cate Schaeffer and Johannes van der Zouwen (eds.). 2002. Standardization and Tacit Knowledge. Interaction and Practice in the Survey Interview. New York: John Wiley.

Missionary Handbook. 2002. Salt Lake City, UT: The Church of Jesus Christ of Latter-Day Saints.

Moerman, Michael. 1988. Talking Culture: Ethnography and Conversation Analysis. Philadelphia, PA: University of Pennsylvania Press.

Mondada, Lorenza. 2009. 'Emergent Focused Interactions in Public Places: A Systematic Analysis of the Multimodal Achievement of a Common Interactional Space.' Journal of Pragmatics 41: 1977-1997.

Nekvapil, Jiří. 2000. 'On Non-self-evident Relationships between Language and Identity: How Germans Do Not Speak German and Czechs Do Not Speak Czech.' Multilingua 19 (1): 37-53. 
Neustupný, Jiří V. 2003. 'Japanese Students in Prague: Problems of Communication and Interaction.' International Journal of the Sociology of Language 162: 125-143.

Parry, K. 2001. 'The Mormon Missionary Companionship.' Pp. 182-206 in Contemporary Mormonism: Social Science Perspectives, edited by M. Cornwall, T. B. Heaton and L. A. Young. Urbana and Chicago, IL: University of Illinois Press.

Psathas, George. 1995. Conversation Analysis: The Study of Talk-in-Interaction. Thousand Oaks, London, New Delhi: Sage.

Sacks, Harvey. 1992. Lectures on Conversation. Oxford: Basil Blackwell.

Sacks, Harvey, Emanuel A. Schegloff and Gail Jefferson. 1974. 'A Simplest Systematics for the Organization of Turn-taking for Conversation.' Language 50: 696-735.

Schegloff, Emanuel. 1979. 'Identification and Recognition in Telephone Conversation Openings.' Pp. 23-78 in Everyday Language: Studies in Ethnomethodology, edited by G. Psathas. New York: Irvington Publishers.

Schegloff, Emanuel A. and Harvey Sacks. 1973. 'Opening Up Closings.' Semiotica 8 (4): 289-327.

Shepherd, Gary and Gordon Shepherd. 1998. Mormon Passage: A Missionary Chronicle. Urbana and Chicago, IL: University of Illinois Press.

Shepherd, Gordon and Gary Shepherd. 2001. 'Sustaining a Lay Religion in Modern Society: The Mormon Missionary Experience'. Pp. 161-181 in Contemporary Mormonism: Social Science Perspectives, edited by M. Cornwall, T. B. Heaton, and L. A. Young. Urbana and Chicago, IL: University of Illinois Press.

Sherman, Tamah. 2006. 'Uncovering Institutionally Imposed Norms through the Interaction Interview: Mormon Missionaries in the Czech Republic.' Pp. 1-12 in Language Management for the Coming Multicultural Society (= Language Management in Contact Situations. Vol. 4). Report on the Research Projects No. 129, edited by H.Muraoka. Chiba: Chiba University, Graduate School of Social Sciences and Humanities.

Sherman, Tamah. 2007. 'Proselyting in First-contact Situations.' Unpublished PhD dissertation, Institute of Linguistics and Finno-Ugric Studies, Faculty of Arts, Charles University in Prague.

Smout, Kary D. 1988. 'Senkyoshigo: A Missionary English of Japan.' American Speech 63 (2): 137-149.

Watson, Rod. 1997. 'Some General Reflections on "Categorization" and "Sequence" in the Analysis of Conversation.' Pp. 49-76 in Culture in Action: Studies in Membership Categorization Analysis, edited by S. Hester and P. Eglin. Washington, DC: University Press of America.

Wilson, William A. 2001. 'Powers of Heaven and Hell: Mormon Missionary Narratives as Instruments of Socialization and Social Control.' Pp. 207-217 in Contemporary Mormonism: Social Science Perspectives, edited by M. Cornwall, T. B. Heaton and L. A. Young. Urbana and Chicago, IL: University of Illinois Press. 


\section{Appendices}

\section{Appendix 1: Transcription conventions}

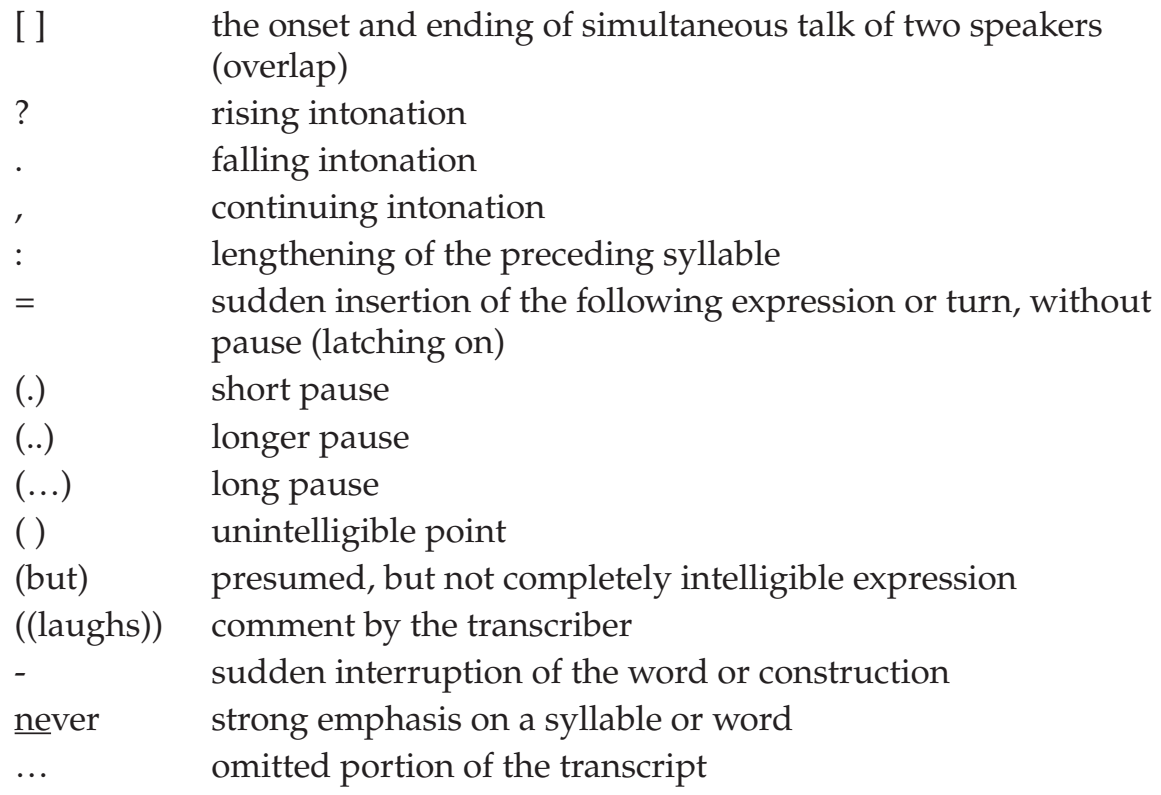

\section{Appendix 2: List of abbreviations}

FCPP - First-contact public proselyting situations

LDS - (Church of Jesus Christ of) Latter-Day Saints

EM - Ethnomethodology

CA - Conversation Analysis

\section{Appendix 3: Original Czech recorded data extracts}

\section{Example 4}

1. M1: uh prosím vás mohli bychom mluvit s vámi?

2. C32: já spěchám

3. M1: ((fast)) no my taky spěcháme jenom my jsme tady jako

4. dobrovolníci misionárii ze církve ježiše krista, a tady my

5. nabízíme několik uhm služeb, napríklad my tady učíme zdarma 
6. angličtinu nevím jestli umíte anglicky náhodou nebo jestli

7. znáte někoho

8. C32: umím trochu ((laughs))

9. M1: yeah? domluvíte se?

10. C32: domluvím

11. M1: yeah? ((slowly)) what is your name?

12. C32: my name is ladislava

13. M1: d- well nice to meet you.

\section{Example 5}

1. M1: dobrý den paní

2. C13: dobrý den

3. T: dobrý den

4. $((\ldots))$

5. M1: znáte nás?

6. C13: neznám.

7. M1: neznáte

8. C13: neznám ale

9. M1: slyšíte náš moje přízvuk že jo? [yeah ((laughs))]

10. C13: [vy jste asi cizinci]

11. M1: my jsme my jsme $\mathrm{z}$ ameriky

12. C13: aha studenti?

13. M1: [cože?]

14. M3: [uuh ne]

15. M1: já jsem $z$ kalifornie

16. C13: aha

17. M1: my jsme tady jako dobrovolníci

18. C13: $\mathrm{mm} \mathrm{hmm}$

19. M1: uh (.) vy mluvíte anglicky náhodou?

20. C13: bohužel

21. M1: ne?

22. C13: bohužel celá rodina jo moje ale já ne

23. ((laughter))

24. M1: jo? víte co? možná můžete (.) (přijít na to) (.) [u nás] ((hands her

25. flyer))

26. C13:

[no děkuju]

27. M1: my učíme (.) zdarma angličtinu tady 


\section{Example 6}

35. M1: a to je jedna věc který my tady děláme

36. C34: $\mathrm{mm} \mathrm{hmm}$

37. M1: a další věc my učíme kurs o tom jak přestat kouřit,

38. C34: $\mathrm{mm}$ hmm no tak já nekouřím no ((laughs))

39. M1: no dobrý to nemáte ten problém ((laughs))

40. C34: dobrý.

41. M1: a poslední?

42. C34: no

43. M1: už jsem mluvil trochu o tom že my jsme tady jako misionáři

44. ale, nevím jestli jste slyšel o nás? nebo jestli vy jste

45. věřící vůbec?

\section{Example 8}

170. M1: a co věříte vy?

171. C33: uh: spíš uh jako- nejsem úplně věřící ale (.) spíš jako (.) takový

172. ty buddhistické věci a takovýdle

173. M1: yeah? yeah? slyšel jsem něco o tom jako

174. C33: $\mathrm{mm} \mathrm{hmm}$

175. M1: že mluvil jsem s hodně lidmi? o náboženství a všechno to mi to mi

176. Zajímá jako byl s- já jsem byl v lebedicích?

177. C33: $\mathrm{mm} \mathrm{hmm}$

178. M1: a tam byl jeden hin- hinduist? jak se řekne? to je správný?

179. C33: $\mathrm{mm} \mathrm{hmm} \mathrm{mm}$ hmm $\mathrm{mm}$ hmm

180. M1: yeah? oni mají zajímavý (.) jako (.) kultura a

181. C33: $\mathrm{mm}$ hmm

182. M1: a náboženství (.) a chtěl byste taky slyšet nás náš jako (.) pohled?

183. C33: proč ne?

184. M1: proč ne? tak to je skvělý

185. C33: proč ne proč ne? uh:: $\quad$ (.) takže tady stačí každý úterý že to tam

186. jste?

187. M1: $\mathrm{mm} \mathrm{hmm}$

188. C33: stačí přijít jo?

189. M1: $\mathrm{mm}$ hmm, ale, tam co my normálně děláme

190. C33: $\mathrm{mm} \mathrm{hmm}$

191. M1: je my máme s- tam nebydlíme my

192. C33: $\mathrm{mm} \mathrm{hmm}$

193. M1: znáte zástavku květen?

194. C33: $\mathrm{mm} \mathrm{hmm}$ 
195. M1: my tam bydlíme

196. C33: ano

197. M1: a my máme jako schůzky s lidmi

198. C33: $\mathrm{mm} \mathrm{hmm}$

199. M1: jako pře- (.) nebo skrze týden

200. C33: $\mathrm{mm} \mathrm{hmm}$

201. M1: a mohl bych vám jako prozvonit? až máme čas? ten jako tento př́iští

202. týden mohl bych vám zavolat můžeme domluvit na čas?

203. C33: můžeme

204. M1: no tak skvělý. už my jsme moderní misionáři ((laughter)) to rád

205. ř́kám oops (.) jaký máte číslo?

((7 lines omitted, C33 provides number))

213. M1: tak skvělý.

\section{Example 9}

79. M1: protože my věříme tomu že tyto věci? jako: víra v naších životech

80. může nám pomáhat (.) určit- vy vyp- vy vyp- dyeh- vy vypadáte jako

81. sportovec. vy jste sportovec?

82. C9: hraju fotbal

83. M1: jo?

84. C9: a (.) sázím ((laughs))

85. M1: ((laughs)) a možná jako před zápasem, jako: když to bylo těžký nebo

86. ten další tým byl jako skvělý

87. C9: já dycky když potřebuju když (mám sázeno) vždycky pane bože at' (ho

88. dá)

89. M1: přesně tak ((laughs))

90. C9: včera jsem šel na záchod modlil jsem se a pomohlo mi to

91. M1: opravdu?

92. C9: táta to taky jednou udělal,

93. M1: uh huh?

94. C9: [spíš potřeboval nějaký peníze]

95. M1: [a fungovalo to?]

96. C9: no jo

97. M1: tak vidíte

98. C9: ale musí to bejt na záchodě

99. ((laughter))

100. M1: tak jdeme jdeme jdeme do WC ((laughs))

101. C9: ale jednou jsem to přeháněl nějak moc před zápasem (.) ale (.)

102. $\quad \mathrm{z}$ toho nic nevyšlo čau ((to C10, who is arriving)) 
103. C10: čau

104. C9: hele pod'sem

105. C10: no?

106. C9: tady ř́ká že když se pomodlíš že ti vyjde tiket ((laughter))

107. C10: no

((10 lines omitted))

118. M1: oh my g- (.) přesně tak. ty vogo. tak well? tak už vidíte jako vy

119. jste už jako napůl věřící že jo? jako když se modlíte občas asi

120. věříte že něco je tam že jo

121. C9: no: (.) ale tak jako (aniž bych si to) uvědomoval že [to je vlastně

122. vono]

\section{Example 10}

81. M1: ((laughs)) well, my máme poselství o ježiši kristu (v krat- v

82. krátkosti) uhm tím že je (jistě) hodně církví i když jako nejste

83. věřící

84. C28: $\mathrm{mm}$

85. M1: může (.) asi každý z nás jako (.) my jsme měli věřící zkušenosti

86. možná (.) vy vy vypadáte jako sportovec (.) vy jste sportovec?

87. C28: no:

88. M1: vy taky? (.) ne:?

89. C27: já moc ne

90. M1: a když jste měl jako velký zápas? (.) modlil jste se?

91. C27: ah na snowboardu akorát jezdím

92. M1: oh jo jo (.) [aha takhle]

93. C27: $\quad[()]$

94. M1: jo? já taky snowboard-uju ale v americe tady ne ((laughs)) ta-

95. tady ale (.) jako já jsem mluvil s hodně lidmi a hodně lidí řekli

96. že nejsou věřící (.) ale alespoň věří v nějakou energii nebo možná

97. před velkým zápasem oni se modlili za pomoc nebo něco

98. C28: tak to jsou věřící v tom případě ale

99. M1: jo? ale i i když jako ti lidi? (.) jako řekli předtím že nejsou

100. věřící a právě jsem řekl a co jako před zápasem nebo něco? on řekl

101. je: to jo ((laughs))

102. C27: potom nevědí co říkají v tom případě 